\title{
Accidental Dental Avulsion Caused by Direct Laringoscopy
}

Joana Barros Mourão*, Diogo Magalhães and Germano Neves Pinto Rocha

Anesthesiologist, Centro Hospitalar São João, Anesthesiology, Alameda Professor HernaniMonteiro Oporto, Portugal

*Corresponding author: Joana Barros Mourão, Anesthesiologist, Centro Hospitalar São João, Anesthesiology, Alameda Professor HernaniMonteiro Oporto, Portugal, Tel: 00351966312610; E-mail: joanamourao1@sapo.pt

Copyright: (c) 2014 Mourao JB, et al. This is an open-access article distributed under the terms of the Creative Commons Attribution License, which permits unrestricted use, distribution, and reproduction in any medium, provided the original author and source are credited.

Received date: February 20, 2014; Accepted date: April 07, 2014; Published date: April 18, 2014

\begin{abstract}
Background: Damage to the teeth is one of the most common complications of tracheal intubation. The aim of this study is to provide the knowledge on how anesthesiologists should act when faced with dental avulsion.

Methods: A multiple choice survey made up of eleven questions was delivered at a Portuguese Anesthesiologist meeting. Statistical analysis was performed using the spss17.0 software and all the answers were expressed in descriptive frequency distributions and percentages.

Results: The sample consisted of 65 anesthesiologists, 37 specialists (56.9\%) and 28 internees (43.1\%). In response to, what to do if a tooth came out of its socket, only $13.8 \%$ would put it back. The majority (86.2\%) preferred taking it out despising the possible conditions of the tooth and bone. From the latter group, $90.1 \%$ chose to preserve the tooth and send the patient to a dentist. When reimplantation was considered, a small percentage $(10.8 \%)$ chose to do it immediately. Also $32.3 \%$ decided to reimplant the tooth in the recovery room and the other $32.3 \%$ admitted not knowing when. As to the splinting of the anterior teeth, just $26.2 \%$ of the respondents would consider using it. The others wouldn't, either because it would be their decision (33.8\%) or because they wouldn't know how to do it (40.0\%). In order to determine the evaluation of periodontal conditions, most anesthesiologists confirmed not to use any guidelines $(69.2 \%)$ and $84.6 \%$ of the respondents denied having been taught anything in this particular area.
\end{abstract}

Conclusion: The majority $(86.2 \%)$ confirmed not having been given such information. To help prevent and treat dental avulsion, having knowledge in this area is essential.

Keywords: Dental avulsion; Laringoscopy; Anesthesia complications

\section{Introduction}

During general anesthesia the airway's patency has been the main care given by anesthesiologists. From all available techniques, the tracheal intubation by direct laryngoscopy continues to be the most efficient and fastest technique. It guarantees not only success, but also safety to mechanically maintained airway ventilation [1]. Although it is a tool of great benefit, the technique itself could cause severe dental trauma.

The direct laryngoscopy technique consists of inserting a blade of the laryngoscope, moving the tongue of the patient to his left side [2]. Upon visualization of the epiglottis the laryngoscope is then pulled antero-superiorly to expose the glottis cleft where the orotracheal tube is then inserted. It is during this last step that the majority of dental traumas occurs.It is expected, however, that no pressure should be applied to the teeth, lips and mucosa as well [3]. In a study by Taeko et al. the maximum peak force applied to the superior incisors was $40.2 \mathrm{~N}$ [4]. Bucxand Snijders have also shown that the force transmitted while using the superior incisors as a lever was much higher than normal [5] making it easier to gain access to the glottis. Despite traditional advice to the contrary, the levering movement of the laryngoscope, using the maxillary incisors (or gums), is common practice [6]. From all possible traumas, dental trauma variesfrom 1:1000 to 1:10 [7], being the central maxillary incisors the most struck.
It is of great importance to understand that, oral trauma, due to an unsuitable technique, can cause not only transient lesions (oedema and haemorrhage) but also permanent damage [8], being avulsion the most traumatic one. In a study by Hoffman et al. $20.8 \%$ of all dental trauma were avulsions [9]. This is such a relevant problem that the Medical Defence Union has already named it the most frequent cause of compensation during general anesthesia (63\%) [10].

The aim of this study is to evaluate the level of knowledge that Anesthesiologists have towards an accidental dental avulsion and how they act when faced with one.

\section{Material and Methods}

After approval of The Ethic Council of the Faculty of Dental Medicine of Porto's University, a survey was delivered at a Portuguese Anesthesiologist meeting. The main objective of the questionnaire was to understand how they would act when faced with an accidental avulsion. The survey consisted ofeleven questions presented on Table 1.

\begin{tabular}{|l|l|}
\hline 1$)$ & If a tooth came out of its socket, what would you do? \\
\hline 2) & How would you pick the tooth up? \\
\hline 3) & If taken out should it be cleaned and with what? \\
\hline 4) & If preserved in any liquid which would you use? \\
\hline
\end{tabular}


Page 2 of 4

\begin{tabular}{|l|l|}
\hline 5) & What would you do with the avulsioned tooth? \\
\hline 6$)$ & If reimplantation was an option, when would it be done? \\
\hline 7) & Before reimplantation, which liquid would you irrigate it with? \\
\hline 8$)$ & Regarding dental splinting, what would you use? \\
\hline 9) & $\begin{array}{l}\text { During the pre-surgery consultation, do you do dental/periodontal } \\
\text { evaluation? }\end{array}$ \\
\hline 10) & Were you at any time of your medical training instructed in this area? \\
\hline 11) & If yes, when \\
\hline
\end{tabular}

Table1: Questionnaire

Statistical analysis was performed using thespss 17.0 software package by IBM (SPSS Inc., Chicago, IL, USA) and all the answers were expressed in descriptive frequency distributions and percentages.

\section{Results}

The sample was made up of 65 anesthesiologists, 37 specialists (56.9\%) and 28 internees (43,1\%). $23.1 \%$ were male and $72.3 \%$ female, with an overall average of 10.8 years of experience $(n=64, \sigma=8.33)$ as shown in Table 2 .

\begin{tabular}{|l|l|l|l|l|l|}
\hline & N & Minimum & Maximum & Mean & Std. Deviation \\
\hline Years/experience & 64 & 1.00 & 34.00 & 10.8047 & 8.33220 \\
\hline
\end{tabular}

Table 2: Descriptive statistics of answers about the years of experience

In response to the first question, what to do if a tooth came out of its socket, only $13.8 \%$ would put it back. The majority $(86.2 \%)$ preferred to take it out ignoring the possible conditions of the tooth and bone (Table 3a). From this group, $90.1 \%$ chose to preserve the tooth and send the patient to a dentist (Table 4).

\begin{tabular}{|l|l|}
\hline Question 1 & \\
\hline Take it out, $\mathrm{n}(\%)$ & $56(86.2)$ \\
\hline Put it back in the socket, $\mathrm{n}(\%)$ & $9(13.8)$ \\
\hline Question $\mathbf{2}$ & \\
\hline Root, $\mathrm{n}(\%)$ & $5(7.7)$ \\
\hline Crown, $\mathrm{n}(\%)$ & $27(41.5)$ \\
\hline Any position, $\mathrm{n}(\%)$ & $33(50.8)$ \\
\hline Question 3 & \\
\hline Don't clean it, $\mathrm{n}(\%)$ & $32(49.2)$ \\
\hline water or other, $\mathrm{n}(\%)$ & $16(24.6)$ \\
\hline with a gauze, $\mathrm{n}(\%)$ & $17(26.2)$ \\
\hline Question 4 & \\
\hline Water, $\mathrm{n}(\%)$ & $6(9.2)$ \\
\hline Serum, $\mathrm{n}(\%)$ & $51(78.5)$ \\
\hline Saliva, $\mathrm{n}(\%)$ & $3(4.6)$ \\
\hline
\end{tabular}

\begin{tabular}{|l|l|}
\hline Other, $\mathrm{n}(\%)$ & $1(1.5)$ \\
\hline Don't know, n (\%) & $4(6.2)$ \\
\hline Question 5 & \\
\hline Reimplant , n (\%) & $7(10.8)$ \\
\hline Won't reimplant, n (\%) & $3(4.6)$ \\
\hline Preserve/contact dentist, n (\%) & $54(83.1)$ \\
\hline Don't know, n (\%) & $1(1.5)$ \\
\hline
\end{tabular}

Table 3a: Percentage distribution of answers about tooth avulsion knowledge and procedure

When reimplantation was considered, only a small percentage (10.8\%) would choose to do it immediately and $15.4 \%$ during the maintenance of the anesthesia. Also $32.3 \%$ would decide to reimplant the tooth in the recovery room and the other $32.3 \%$ admitted not knowing the procedure. As to the splinting of the anterior teeth, only $26.2 \%$ of the respondents would consider using it. Most wouldn't, either because they wouldn't find it appropriate (33.8\%) or because they wouldn't know how to (40.0\%) as shown in Table $3 \mathrm{~b}$.

\begin{tabular}{|l|l|}
\hline Question 6 & \\
\hline Immediately after avulsion, $\mathrm{n}(\%)$ & $7(10.8)$ \\
\hline During anaesthesia, $\mathrm{n}(\%)$ & $10(15.4)$ \\
\hline During emergency of anaesthesia, $\mathrm{n}(\%)$ & $1(1.5)$ \\
\hline Recovery, $\mathrm{n}(\%)$ & $21(32.3)$ \\
\hline Other, $\mathrm{n}(\%)$ & $5(7.7)$ \\
\hline Don't know/ contact dentist, $\mathrm{n}(\%)$ & $21(32.3)$ \\
\hline Question 7 & \\
\hline Serum, $\mathrm{n}(\%)$ & $41(63.1)$ \\
\hline Hydrogen peroxide, $\mathrm{n}(\%)$ & $2(3.1)$ \\
\hline Alcohol, $\mathrm{n}(\%)$ & $2(3.1)$ \\
\hline Other, $\mathrm{n}(\%)$ & $4(6.2)$ \\
\hline Don'tknow, $\mathrm{n}(\%)$ & $16(24.6)$ \\
\hline Question 8 & \\
\hline Don't use splint, $\mathrm{n}(\%)$ & $22(33.8)$ \\
\hline Resin, $\mathrm{n}(\%)$ & $12(18.5)$ \\
\hline Rigidsplint, $\mathrm{n}(\%)$ & $2(3.1)$ \\
\hline Flexible splint, $\mathrm{n}(\%)$ & $3(4.6)$ \\
\hline Don't know, $\mathrm{n}(\%)$ & $26(40.0)$ \\
\hline
\end{tabular}

Table 3b: Percentage distribution of answers about tooth avulsion knowledge and procedure

In order to determine the evaluation of periodontal conditions before surgery, most anesthesiologists confirm not having used any guidelines $(69.2 \%)$ in comparison to $27.7 \%$ that actually use them. 
Page 3 of 4

Finally, $84.6 \%$ of the respondents denied having been taught anything in this particular area (Table 3c).

\begin{tabular}{|l|l|}
\hline Question $\mathbf{9}$ & \\
\hline Guidelines, $\mathrm{n}(\%)$ & $18(27.7)$ \\
\hline No guidelines, $\mathrm{n}(\%)$ & $45(69.2)$ \\
\hline Don't evaluate, $\mathrm{n}(\%)$ & $2(3.2)$ \\
\hline Question $\mathbf{1 0}$ & \\
\hline Yes, $\mathrm{n}(\%)$ & $9(13.8)$ \\
\hline No, $\mathrm{n}(\%)$ & $56(86.2)$ \\
\hline Question 11 & \\
\hline Medical school, $\mathrm{n}(\%)$ & $0(0)$ \\
\hline Internee, $\mathrm{n}(\%)$ & $9(13.8)$ \\
\hline Without answer, $\mathrm{n}(\%)$ & $56(86.2)$ \\
\hline
\end{tabular}

Table 3c: Percentage distribution of answers about tooth avulsion knowledge and procedure

\begin{tabular}{|l|l|l|l|l|l|}
\hline $\begin{array}{l}\text { Question 5/ } \\
\text { Question 1 }\end{array}$ & Reimplant & $\begin{array}{l}\text { Won't } \\
\text { Reimplan } \\
\mathbf{t}\end{array}$ & Conserve & $\begin{array}{l}\text { Don't } \\
\text { Know }\end{array}$ & Total \\
\hline $\begin{array}{l}\text { Take the tooth } \\
\text { out }\end{array}$ & $1(1.8 \%)$ & $3(5,3 \%)$ & $\begin{array}{l}51 \\
(90,1 \%)\end{array}$ & $1(1.8 \%)$ & $56(100 \%)$ \\
\hline Put it back & $6(66,7 \%)$ & 0 & $3(33,3 \%)$ & 0 & 9 \\
\hline
\end{tabular}

Table 4: Crosstab relationship between Question 1 and 5

\section{Discussion}

Understanding and knowing the conditions and protocols for a viable reimplant of an avulsioned tooth is of great importance. Although time is crucial for the success of reimplantation, doing this procedure after its avulsion is often not possible during laryngoscopy. As shown, $86.2 \%$ of the anesthesiologists prefer to take the tooth out and preserve it $(90.1 \%)$. Even when the reimplantation option was given, the majority (83.1\%) still preferred to preserve it and later send the patient to a dentist. This would reduce drastically the chances of viable tooth reimplantation. Even so, all the respondents were asked when a tooth should be reimplanted. Only $10.8 \%$ would do it immediately and $15.4 \%$ during the maintenance of the anesthesia. According to Adersson and when indicated, reimplantations within 15 min after avulsion have a favorable long-term prognosis [11]. Assuming it is not a minor intervention, this makes of the option chosen the best time approach for reimplantation in the surgery room. Still, most respondents would choose to do it after that time (41.5\%) or wouldn't know when to carry it out (32.3\%).

Immediate reimplantation is, most of the times, impossible and the condition of the cells of the periodontal ligament is of utmost importance. After a dry time of $60 \mathrm{~min}$ or more, all periodontal ligament (PDL) is non-viable [12] and, therefore, a compatible physiologic storage medium should be used [12-14]. The majority of the respondents $(78.5 \%)$ answered correctly, selecting a saline solution (Serum). Only $9.2 \%$ chose water as its storage, which should also be avoided, since it causes rapid cell lysis and inflammation on reimplantation due to the hypotonic environment. Therefore it is not advisable to use it as a storage medium [14].

Knowing how to handle a tooth correctly is also important in order to reduce the probability/risk of root absorption and/or ankylosis [15]. If a tooth, after avulsion, is picked up by the root, as seen in $7.7 \%$ of the answers, the chances of damaging the PDL are high and should hence be avoided. Even so, $50.8 \%$ would pick it up in any convenient position. Almost half of the respondents wouldn't clean it (49.2\%), Cleaning should be refrainedsince the surgery room is already sterile. This action will further damage the PDL, not so much if water is used (24.6\%) but drastically if cleaned with a gauze $(26.2 \%)$, increasing the chances of akylosis and root absorption.

A Flexible splint for the avulsioned teeth is recommended within 7-14 days [12,16] or 4-8weeks if alveolar fracture is visible [13]. When using flexible splints, it is possible for a tooth to have a slight motion, promoting periodontal healing [12] with less ankylosis [15]. In the present study, the lack of such information is obvious, considering this choice was only made by $4.6 \%$ of the respondents. The majority chose either not to use it [8], or didn't know how to (40\%).

Anesthesiologists also need to take into account that not all teeth are viable for reimplantation (e.g. advanced periodontal disease, immunosuppression and severe caries) [12], hence the importance of knowing how to make a correct periodontal evaluation before surgery. It is expected that a majority of these avulsions should occur in patients with grade 2 and 3 mobility, in which replantation isn't advised. Nevertheless, young permanent teeth with open apex still remain a risk group where this treatment is necessary as well as in other particular cases. This way, guidelines could help anesthesiologist raise questions to whether reimplantation should be practiced in case of avulsion, and even take measures to avoid this trauma. Prevention should always be mandatory, either to prevent dental avulsions or dental fractures. After being asked, $69.2 \%$ of the respondents affirm not using any guidelines for a pre-surgical consultation and $3.1 \%$ don't do dental checkup at all. This is worrying in a way that patients with moderate to severe periodontal disease are highly likely to suffer from traumatic dental avulsion where previous dental splinting could help lower or even prevent it from happening [12]. However, even if damage to the tooth cannot be prevented, it is of great importance that when faced with an unexpected avulsion, the anesthesiologist knows if the reimplantantion option is viable or not.

Overall, as seen in this study, knowledge of this practice is somehow unknown to anesthesiologists. This becomes a problem in a way that anesthesiologists cannot guarantee, whenreimplantation is indicated, a good outcome from the procedure itself leaving the patient with a severe dental mutilation. This will not only affect the aesthetics and difficulty to speak, as it will also become a reason for social segregation. The majority $(86.2 \%)$ of the respondents confirm not having been given any information on this particular area.

\section{Conclusion}

To treat dental avulsion, anesthesiologists need such knowledge that must be undertaken during their internship. It's mandatory using guidelines for dental and oral evaluation and to replantation of accidental avulsed teeth duringlaryngoscopy. 
Citation: Mourão JB, Magalhães D, Rocha GNP (2014) Accidental Dental Avulsion Caused by Direct Laringoscopy. J Anesth Clin Res 5: 400. doi:10.4172/2155-6148.1000400

Page 4 of 4

\section{References}

1. Nouruzi-Sedeh P, Schumann M, Groeben H (2009) Laryngoscopy via Macintosh blade versus GlideScope: success rate and time for endotracheal intubation in untrained medical personnel. Anesthesiology 110: 32-37.

2. Scott J, Baker PA (2009) How did the Macintosh laryngoscope become so popular? PaediatrAnaesth 19 Suppl 1: 24-29.

3. Janeway HH (1913) Intratracheal anesthesia from the standpoint of the nose, throat and oral surgeon with a description of a new instrument for catheterizing the trachea. Laryngoscope 23: 1082-1090.

4. Fukuda T, Sugimoto Y, Yamashita S, Toyooka H, Tanaka M (2011) Forces applied to the maxillary incisors during tracheal intubation and dental injury risks of intubation by beginners: a manikin study. ActaAnaesthesiol Taiwan 49: 12-15.

5. Bucx MJ, Snijders CJ (1996) Force, torque, and stress relaxation with direct laryngoscopy. AnesthAnalg 83: 1130-1131.

6. Bucx MJ, Snijders CJ, van Geel RT, Robers C, van de Giessen H, et al. (1994) Forces acting on the maxillary incisor teeth during laryngoscopy using the Macintosh laryngoscope. Anaesthesia 49: 1064-1070.

7. Lockhart PB, Feldbau EV, Gabel RA, Connolly SF, Silversin JB (1986) Dental complications during and after tracheal intubation. J Am Dent Assoc 112: 480-483.

8. Aromaa U, Pesonen P, Linko K, Tammisto T (1988) Difficulties with tooth protectors in endotracheal intubation. ActaAnaesthesiolScand 32: 304-307.
9. Hoffmann J, Westendorff C, Reinert S (2005) Evaluation of dental injury following endotracheal intubation using the Periotest technique. Dent Traumatol 21: 263-268.

10. Aitkenhead AR (2005) Injuries associated with anaesthesia. A global perspective. Br J Anaesth 95: 95-109.

11. Andersson L, Bodin I (1990) Avulsed human teeth replanted within 15 minutes--a long-term clinical follow-up study. Endod Dent Traumatol 6: 37-42.

12. Andersson L, Andreasen JO, Day P, Heithersay G, Trope M, et al. (2012) International Association of Dental Traumatology guidelines for the management of traumatic dental injuries: 2. Avulsion of permanent teeth. Dent traumatol 28: 88-96.

13. Trope M (2002) Clinical management of the avulsed tooth: present strategies and future directions. Dent Traumatol 18: 1-11.

14. Blomlöf L (1981) Milk and saliva as possible storage media for traumatically exarticulated teeth prior to replantation. Swed Dent J Suppl 8: 1-26.

15. Andreasen JO, Andreasen FM, Andersson L (2007) Textbook and color atlas of traumatic injuries to the teeth. (4thedn), Wiley-Blackwell, Oxford, UK, 444-488.

16. Maria AMA (1999) TratamentoClínico dos TraumatismosDentários. (1stedn), São Paulo: ArtesMédicas, 223-265. 